\title{
Photovoltaic Technology Integration with Tensile Membrane Structures - a Critical Review
}

\author{
Vuk MILOŠEVIĆ, Janusz MARCHWIŃSKI*
}

\begin{abstract}
Tensile membrane structures and photovoltaic technology have been developing completely independently one from the other until recently. After the realization that PV-membrane integration would benefit both of these systems, research on their common application began. Photovoltaic panels increase the energy efficiency of tensile membrane structures, while at the same time tensile membrane structures provide large areas for harvesting solar power. This symbiosis has been tested and proven both scientifically and in practice. This paper presents the state of the art of scientific research concerning tensile membrane structures fitted with photovoltaic technology. Based on this knowledge, possibilities and problems connected with photovoltaic technology integration in tensile membrane structures were identified. It was observed that they refer to three main types of properties affected by the integration, i.e.: thermal, energy, and structural properties. The main factors influencing these properties are PVmembrane integration methods and PV-membrane geometry. Furthermore, the conducted analysis allowed for identification of insufficiently explored areas in this field and recommendations for further research. The aim of this paper is to help in systematizing the existing knowledge which should have a positive effect to achieving widespread application of photovoltaic integrated membrane structures.
\end{abstract}

Keywords: energy efficiency; photovoltaic technology; PV-membrane integration; solar power; tensile membrane structures

\section{INTRODUCTION}

Both tensile membrane structures and photovoltaic technology have been researched actively, but separately, for more than 50 years. Recent advancements in the photovoltaic technology made PV panels thin, lightweight and flexible. This allowed for their much better integration in buildings. However, integration of photovoltaic technology and tensile membrane structures particularly stands out. Being thin, lightweight and flexible as well, membranes appear to be a perfect match for the advanced PV panels. In addition to this, tensile membranes are well known for being visually very attractive. Therefore, integration of tensile membranes, as a structural system, and photovoltaic panels, as a technological system, brings significant benefits to both of these components. With energy efficiency being one of the imperatives of our time, PV could provide the much needed sustainability for enclosed membrane structures, or increase the energy efficiency of buildings covered with open membranes. In return, this integration contributes to further promotion of PV panels through their application on such appealing structures, as not only energy performance but also aesthetics should be taken into consideration in low-energy buildings. Additionally, membranes provide large areas for application of novel photovoltaic technology. Unlike other structural systems, tensile membranes make full use of the advanced properties of PV panels by stretching their possibilities to the limit, and even demanding further improvements.

The potential for creating an innovative system that would lead to additional enhancements of tensile membrane structures is an incentive for new scientific researches. This paper presents the state of the art in the scientific research of photovoltaic integrated tensile membrane structures. Several aspects of PV-membrane integration have already been investigated; however, more scientific knowledge is necessary in order to begin with the widespread application of these systems. To the authors' knowledge there are no published papers which systematize the existing knowledge in this specific area. The aim of this paper is to provide an overview of the existing work and set a basis for further research. By detecting the aspects which are still not sufficiently investigated, this paper underlines the areas suitable for additional exploration. Such new findings would further encourage the application of PV technology and its integration with tensile membrane structures.

The structure of this article is as follows. First, basic properties of tensile membrane structures are shown. Then, development and current achievements of photovoltaic technology are elaborated. In the next sections, published researches on integration of photovoltaic technology into tensile membrane structures are reviewed, summarized and discussed. Finally, conclusions about the potentials and problems of this integration are presented.

\section{TENSILE MEMBRANE STRUCTURES}

Tensile membrane structures are in use since mid- $20^{\text {th }}$ century. They radically differ from conventional structural systems made from concrete, steel or timber in many aspects. While traditional structures generally resist external loads through bending and compression, membrane structures are designed to be in constant tension. For this reason they are pretensioned and have double curved forms. Prestressing is done either mechanically or pneumatically. Their double curved form can be both with negative and positive Gaussian curvature. Negative Gaussian curvature is paired with mechanical prestressing, while positive Gaussian curvature is achieved by using air overpressure. Examples of these two basic types of tensile membrane structures are given in Fig. 1.

Other properties of tensile membrane structures came as a consequence of their tensile nature. Extraordinary thinness of membrane materials is the most noticeable one. There are two basic types of membrane materials - woven and foil materials. Woven or textile membrane materials have the thickness of about $1 \mathrm{~mm}$. Foil materials, with ETFE foil being most commonly used, are only a fraction of $1 \mathrm{~mm}$ thick. Due to this, their weight is minimal and usually about $1 \mathrm{~kg} / \mathrm{m}^{2}$. This makes tensile membrane structures several tens or hundreds of times lighter than traditional structures, depending on the type of supporting 
structure. This is not just a significant structural advantage, but also an economic convenience. However, this does not limit tensile membrane structures from spanning few tens of meters without internal supports. It is common for textile membranes to be mechanically prestressed and have anticlastic curvature, while foils are usually pneumatically prestressed and with synclastic curvature, although this is not a rule.
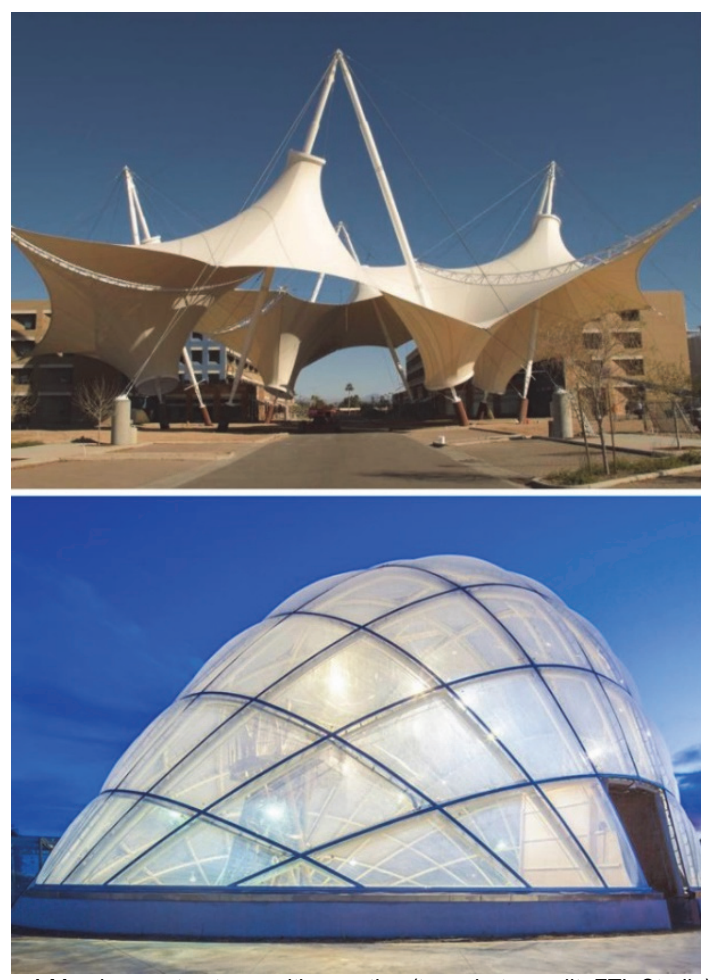

Figure 1 Membrane structures with negative (top, photo credit: FTL Studio) and positive Gaussian curvature (bottom, photo credit: Quintin Lake)

Despite the fact that tensile membrane structures have some superior structural properties, this was not the reason for their expansion in the last decades. The main reason of their popularity is their aesthetics. Double curved forms, which are a structural necessity for tensile membranes, are considered to be extremely elegant and appealing. Both architects and the public appreciate the offset from orthogonal architecture that membrane structures offer. At the same time, textile membranes provide for visually pleasant interior spaces. Being translucent, they light the interior space with diffuse light during daytime. If lit at night, they become large sculptures or light spectacles when viewed from the exterior. ETFE membranes are regarded as a lightweight substitute for heavy glass covers. They can be transparent and therefore also provide excellent internal visual environment. Further properties of membrane structures can be found in literature $[1,2]$.

In the preceding part of this paper, only advantages of tensile membrane structures have been mentioned. However, they also have a few important disadvantages. Despite the fact that they are in use for more than half a century, tensile membranes are still not properly codified in Europe, even though some guidance exists [3, 4]. The regulation in the form of Eurocode for design of tensile membrane structures is expected to be completed in the years to come. In the USA however, an appropriate standard already exists [5]. Structural analysis of tensile membranes is complex and requires specialized software [6]. Next, due to their thinness, membranes are very flexible, thus allowing for large deflections under external loading. They are unusually susceptible to point load actions [7-9]. This makes them unsuitable for creating multi-storey buildings. In addition to this, their thermal properties make them unfit for use in residential buildings. Thin membrane material is unable to provide any significant heat transfer resistance. Therefore, energy efficiency of membrane structures is low $[10,11]$. This has resulted in tensile membranes being frequently used to cover, and not to enclose a space $[12,13]$. They are most commonly applied to cover sports stadia, parking lots, pedestrian walkways, public spaces and open theatres.

Several methods have been developed with the aim to increase the energy efficiency of tensile membrane structures. The most straightforward one is the addition of thermal insulation on the inner side of the membrane. This method can significantly improve the thermal resistance, but impairs other qualities of membranes, such as internal aesthetics, visual comfort and thinness. Another method is forming multi-layer membranes [14]. The air between the membranes can be enclosed or heated in order to improve the thermal properties of the building [15]. However, this also reduces the amount of light in the interior, makes the structure more expensive and consumes more energy and material. Recently, with the development of solar power technology, an idea appeared to produce energy right at the membrane. This paper explores the state of the art of the idea of integrating tensile membrane structures and photovoltaic panels.

\section{PHOTOVOLTAIC TECHNOLOGY}

The history of photovoltaic (PV) technology starts with the year 1839 when Antoine Becquerel discovered the photovoltaic effect. For many years the interest in this technology had been relatively low until the 1950s when the cosmic era started. A decade later, the PV technology met with a widespread interest in non-cosmic applications but it took another 20 years for it to emerge in the building sector [16].

The PV technology is based on solar (PV) cells that use photovoltaic effect allowing for solar energy transformation into electric power. Currently three generations of PV cells are distinguished in the systematization of the technological evolution of PV (section 3.1). Together with the technological progress, it is possible to identify architectural evolution of PV cells application, which can be summarized in the authors' systematization (section 3.2).

\subsection{Technological Generations of Solar (PV) Cells}

The first generation solar (PV) cells are represented by silicon crystalline (c-Si) technology. One can distinguish: - monocrystalline silicon (m-Si) cells: they are produced from silicon crystals with an ordered internal structure. They can be recognized by their appearance: the links are in the shape of a square whose corners are cut off. This shape affects the distribution of cells in the module. Monocrystalline cells are currently the most expensive cells on the market, but their high price is compensated by 
the highest efficiency and the longest life among all current cell production technologies. They can be also distinguished by colour, since as a rule they are black.

- polycrystalline silicon cells (p-Si): they are made of silicon wafers arranged irregularly in relation to their crystal structure. The cost of producing this type of cell is lower than that of $\mathrm{m}-\mathrm{Si}$ cells. However, they are characterized by lower efficiency. They can also be recognized by colour because the polycrystalline plates are blue. Low price affects their popularity on the market.

The first generation solar cells, although considered to be obsolete, is still the most popular photovoltaic technology, comprising $\sim 90 \%$ of the global production. This is due to the following facts regarding the silicon:

- global availability and non-toxicity,

- $\quad$ high efficiency reaching 25\% (c-Si cells) [17].

The main disadvantages are economical ineffectiveness and, because of relatively big thickness, low application adaptability.

The second generation solar cells are represented by the thin-film cell technology. They are being manufactured as:

amorphous silicon (a-Si) cells,

cadmium telluride (CdTe) cells,

CIS (CuInSe 2 ) cells.

The main advantage of the thin-film cell technology is a serious reduction of manufacturing costs. This is the result of the lower material demand and simplified structure. Because of the lower thickness, the second generation of solar cells provides more extensive scope of application resulting from their higher physical adaptability.

Thin cells technology features lower efficiency, reaching usually a dozen per cent $[18,19]$, however, a huge development is reported lately (some technologies can exceed 20\%) [20]. Another disadvantage related to a-Si solar cells is Staebler-Wronski effect resulting in efficiency degradation. It occurs within a couple of days after production and can amount to 20\% [21]. Performance comparison of several first and second generation cells has been conducted [22].

The third generation solar cells are less commercially advanced 'emerging' technologies. The most promising and relatively advanced technologies include:

organic photovoltaics (OPV): uses organic semiconductive materials (e.g. polymers). OPV's great strength lies in the diversity of organic materials to be used. In contrast to the non-organic technologies, OPV cells may be regarded as a truly environmentally friendly solution, especially promising in the context of utilization problems. Another advantage is connected with the so called ultrathin OPV and its low weight as well as good mechanical properties (flexibility) [23]. OPV's drawbacks are high risk of damage at high temperatures, instability of parameters in the perspective of long time use, relatively low efficiency (up to $10 \%$ ) [24],

- perovskite solar cells (PSC): include a perovskite structured compound, most commonly a hybrid organicinorganic lead or tin halide-based material, as the lightharvesting active layer. Perovskite materials, such as methylammonium lead halides and all-inorganic cesium lead halide, are cheap to produce and simple to manufacture. Their expected substantial advantage is high efficiency comparative to first generation PV cells. At present, the most challenging issue in perovskite solar cells is long-term stability (humidity is demonstrated to be one of the possible causes for the degradation of perovskites) $[25,26]$. Another urgent issue is standardizing the aging and efficiency measurements of PSC modules by establishing a reliable and transferable methodology that can correctly reflect the device's true performance [27].

- dye-sensitized solar cells (DSSCs): are de facto photochemic cells using normal processes that occur in every plant. Their action is based on the photosynthesis scheme. DSSC convert solar energy into electricity using synthetic dyes to replace chlorophyll in plants. DSSC materials such as titanium oxide $\left(\mathrm{TiO}_{2}\right)$ are inexpensive, abundant and innocuous to the environment. They are also less prone to contamination and are processable at ambient temperature [28].
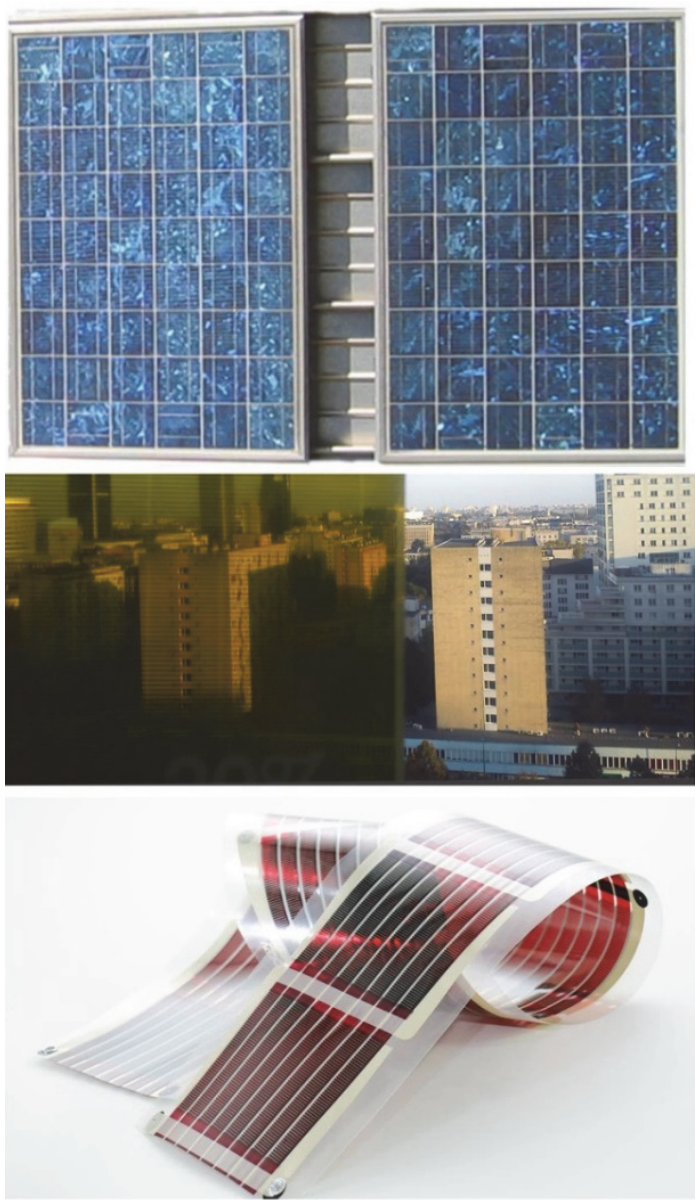

Figure 2 Examples of three technological PV cells generations: p-Si cells (top Shell PV, photo - authors archive); semi-transparent a-Si cell (middle, ONYX photo - authors archive), OPV cells (bottom, Infinity PV, photo credit: Infinity PV)

Compared to conventional silicon solar cells, the DSSC technology provides lower power conversion efficiency but also reduced material and manufacturing costs. The common advantageous features of all the above third generation technologies is their flexibility and physical adaptability. The technology allows for obtaining variable physical features like shapes, colours and transparency. The other, currently less popular thirdgeneration solar cells are copper zinc tin sulphide (CZTS) and quantum dot solar cells [29]. 
Further, tandem technologies are included in the group representing third generation solar cells. Their distinguishing feature is the structure. The tandem solar cells consist of two or more materials having different energy characteristics. Each material absorbs the part of solar energy which it can most effectively convert to electricity. This allows for extraordinarily high efficiencies $(30 \%)$, although it negatively influences production costs. Three-component thin-film modules are used based on amorphous silicon with hydrogen and germanium alloys. In space technology, ternary cells using gallium arsenide (GaAs) and its alloys are used. The examples of the three technological PV cells generations are given in Fig. 2.

\subsection{Architectural Generations of Solar (PV) Cells Application}

The first architectural generation of PV cells application relates to Building Added Photovoltaics (BAPV) idea. PV cells made of crystalline silicon, to be manufactured as framed photovoltaic modules, were applied in a building as a separate technological "appliance". This attitude, although present up to now, was characteristic for the first application of PV technology in architecture and dates back to early 1980s. Few possibilities were left for the aesthetic integration of this element with the architecture of the object. Architectural and aesthetic aspects played a minor role. Emphasis was placed on engineering considerations, and attention focused on improving PV modules as components generating electricity. PV modules were usually placed on the steel support structure on flat roofs. In the case of pitched roofs, they could be installed without using a spatial frame. Their formal and aesthetic features meant, however, that the distinctness of the PV modules in relation to the rest of the roofing was also strongly visible. This was due to limited colour (black or navy blue) and shapes palette (rectangular flat panels) available. For this reason it has become common to hide a set of these elements from the viewer of the building from the ground position.

The second architectural generation of PV cells application can be defined as Building Integrated Photovoltaics idea (BIPV) based on the first and second technological generation PV cells. First BIPV applications took place in the late 1980s. The idea relies on replacing a traditional constructional material with a PV module. This, as a rule, is believed to produce a more positive architectural effect, aesthetically integrating PV element with a building structure $[30,31]$, as well as to bring functional benefits [32]. One can distinguish three basic types of the framed or non-framed PV modules application as BIPV [33]:

- PV modules as façade/roof cladding materials: modules are adapted for fixing on facades and the roof of the building replacing traditional cladding elements (e.g. stone slabs, facade panels, tiles, shingle).

- PV modules as glazed façade/roof element: they are sandwich type glazing with a layer of photovoltaic cells placed between two panes. They are non or semi transparent elements. The semitransparency effect is achieved by creating gaps between opaque PV cells that allow light to pass through. The module's permeability is usually between $10-30 \%$, creating a kind of solar control printed glazing.

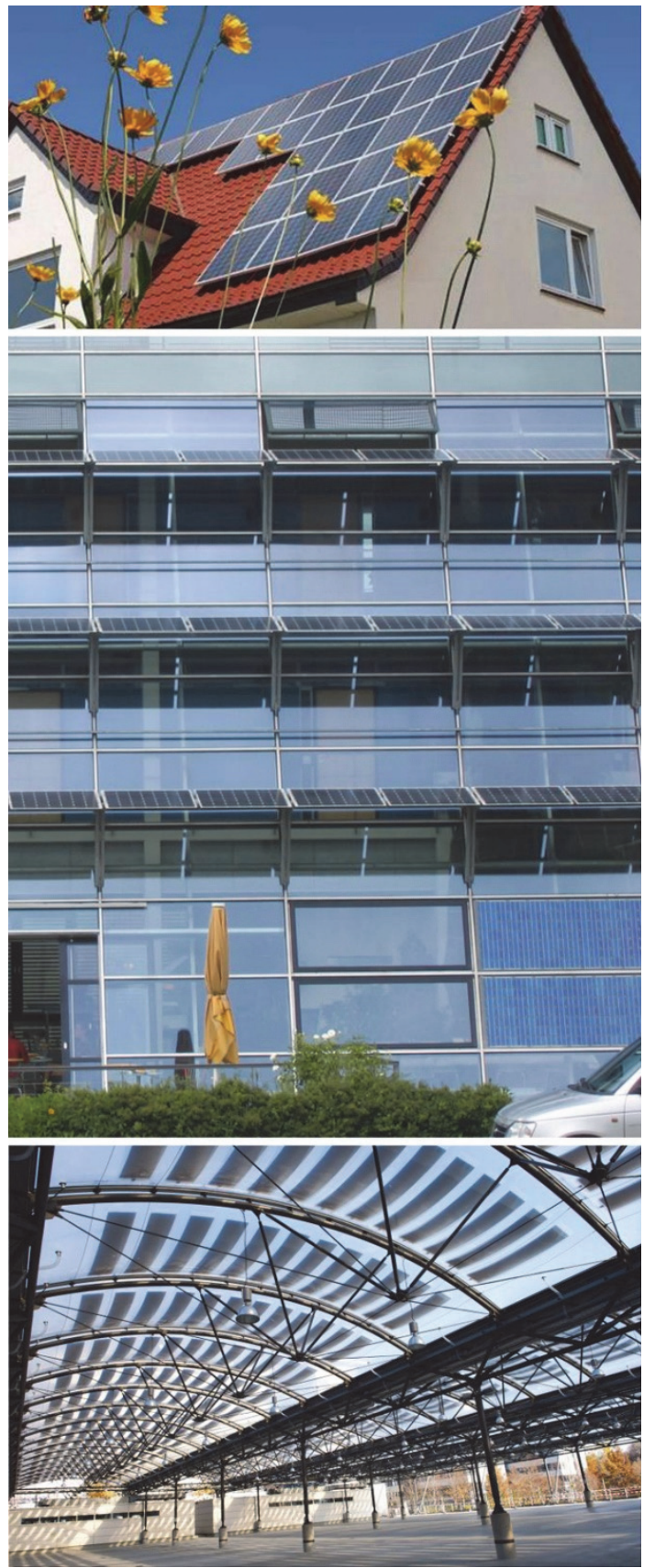

Figure 3 Examples of three architectural generations of PV cells applicationstarting from the oldest: roof-BAPV (top, photo-authors archive), BIPV-spatial shading and glazed façade elements with p-Si PV modules (middle, photoauthors archive), membrane integrated PV cells (bottom, photo credit: @Taiyo Europe, photographer Michael Fischbacher)

- PV modules as spatial shading elements: they are used as solar protection individual elements (blinds, shelves, brise-soleil etc.) or systems ("shadowvoltaic" systems). They can be fixed or movable.

The third architectural generation may be described as a continuation of the previous one with the use of more sophisticated technological measures of the thin-film technology and what is characteristic third-generation solar cells. This results in BIPV unprecedented applications [34]. The discussed architectural PV cells generation can be defined in terms of the following representative solutions: 
- solar windows technology (homogenous semitransparent and almost entirely transparent PV glazing),

- PV cells as a component of switchable glazing technologies [35]

multi-coloured and flexible easy to bend PV modules, - PV cells as a component of modern constructional materials.

The last group of solutions comprises PV integrated membrane structures. The examples of the three architectural generations of PV cells application are given in Fig. 3.

\section{PV INTEGRATED TENSILE MEMBRANE STRUCTURES- REVIEW}

This section reviews the most important published papers regarding the topic of integration of photovoltaics into tensile membrane structures. Two of the important works, the doctoral thesis "Membrane integrated flexible photovoltaics: Integrating organic and thin-film photovoltaics modules into ETFE and PTFE/glass membrane structures", defended in 2013 by Ibrahim Ali Hend, supervised by Alessandra Zanelli and doctoral thesis "Photovoltaic Flexibles: Integrating organic solar cells onto ETFE membrane", defended in 2015 by Fan Zhengyu, supervised by Alessandra Zanelli are not publicly available. Zanelli with colleagues published two articles in 2011 and 2012 about the preliminary activities and the development of prototypes during the research aimed at fabrication of "smart, organic, flexible and translucent photovoltaic cell" [36, 37]. Significant published researches available to authors of this paper are grouped according to their topics in the following subsections.

\subsection{Performance and Behaviour \\ 4.1.1 Simulations}

Ibrahim with co-authors published several articles concerning different aspects of performance and behaviour of integrated PV-membrane structures. One of the papers from 2013 presents a research about the structural behaviour of such systems [38]. The structural behaviour is tested on numerical models of the membrane. A technique for attaching flexible PV to PTFE/glass fabric is presented. This is important for accurate modelling of the structure. Mechanical properties of the membrane and the attaching system are assumed. Four hypar models with different heights, given in Fig. 4, are tested concerning three issues: how does the integration of PV affect the form-finding process, how does the curvature of the membrane impact the system, and how does the structure behave under loads. For the form-finding, it is concluded that the element sizes closer to the size of the attaching system are preferred. Secondly, element sizes are changed during form-finding, therefore few attempts should be made to get the correct sizes of attaching system elements after form-finding is conducted. It was observed that tensile stresses under load get lower as the curvature of the model increases, as shown in Fig. 4. However, the relative increase of stresses from the attaching system is larger for larger curvatures. Authors propose two solutions for reducing the stress increase induced by attaching system. The first one is the change of the shape of the edges of the attaching system, and the second is reducing the stiffness of one of the layers of the fixing system. More investigation of this issue is definitely needed to give final answers to the questions raised in this paper.
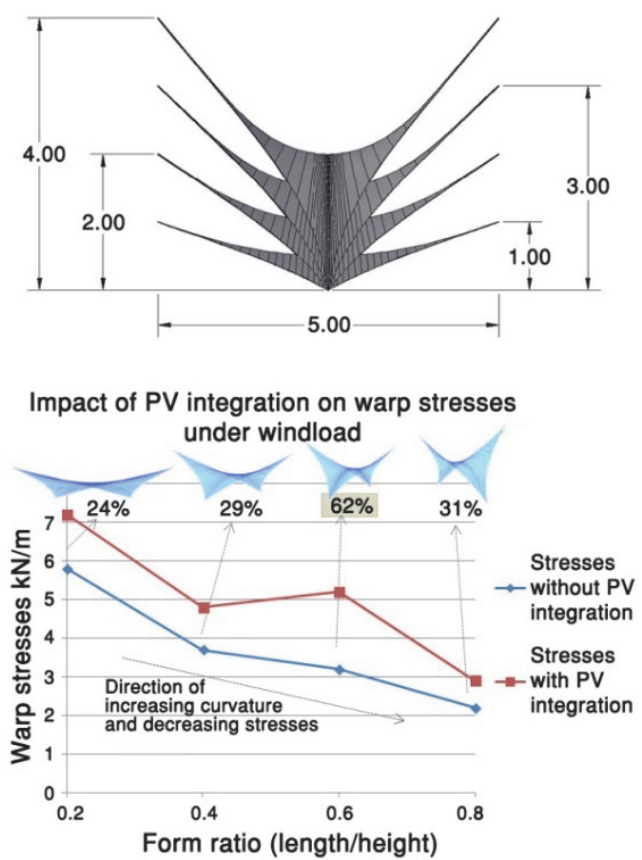

Figure 4 Four investigated hypar models (top), impact of PV integration on warp stresses under wind load (bottom) (authors, based on [38])

The next paper by Ibrahim et al., published in 2016, presents an integrative Grasshopper model used to help in deciding how to best integrate PV cells with the membrane structure [39]. At first, the authors define the challenges of integrating PV onto membranes and list five of them: estimating the yield of PV, membrane stresses and deflections impact on arrangement of PV cells, optimum orientation of PV cells, possible shading of PV cells, and lifetime and stability of PV cells on the membrane. In order to respond to some of these challenges, a parametric model is created in Grasshopper. On the model, three checks are performed in order to find the area of the membrane suitable for application of PV cells. In the first step the software finds all areas of the model with deflections from prestress, snow and wind load which are smaller than the maximum allowable deflection within the same PV module. In the second step the software filters all areas that have the appropriate orientation considering the daily and yearly movement of the sun. This is done for specified locations of the membrane. Finally, in the third step shadowing is checked. As a final result the areas of the membrane that pass all three tests are given and the percentage from the total membrane area suitable for PV cells integration on the membrane is calculated.

The numerical simulations were conducted with TRNSYS on a number of different buildings and different electrochromic shading systems employing additional numerical tools like GenOpt for Optimization of the switching algorithm.

\subsubsection{Testing of PV Modules for Integration}

Another research by Ibrahim et al. published in 2017 was aimed at testing the performance of curved OPV 
modules [40]. These modules have the best efficiency when oriented directly towards the sun; however, double curved form of the membrane structures makes it necessary for the integrated modules to be also curved. This motivated the experiment conducted with different curvatures of the supports. The experiment setup is presented in Fig. 5. Six curvatures were used: 0, 3, 5, 7, 8 and $9 \%$. As expected, the flat modules had the highest output of $9.2 \mathrm{~W}$ and it decreased to 8.6 for the most curved module. The paper gives I - V output for all tested curvatures. The authors conclude that tested OPV modules show good performance even at curved surfaces. Further research should be aimed at experimenting on double curved surfaces and taking into account the daily and yearly movement of the sun in order to compare the performance of membrane-integrated modules to those applied to flat surfaces.

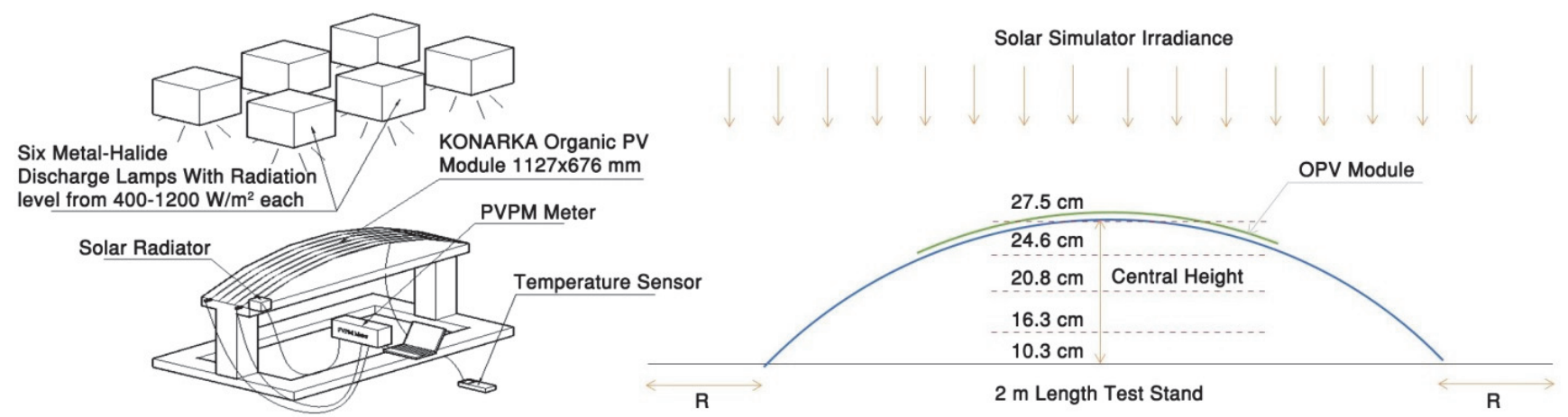

Figure 5 Test stand for measuring performance of curved OPV modules (authors, based on [40])

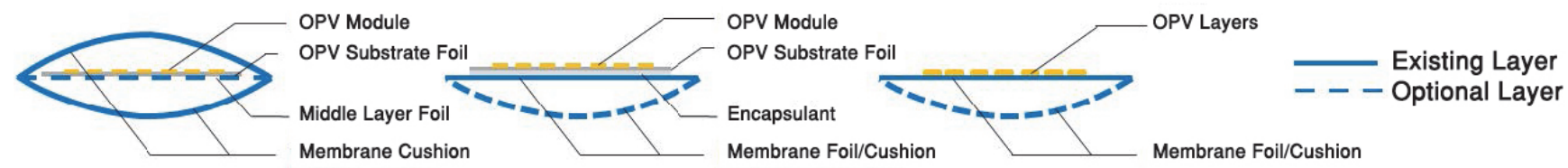

Figure 6 Three strategies for membrane integrated flexible solar cells: Mechanical integration (left), Lamination (middle), Direct printing (right) (authors, based on [41])

In 2016, Fan with colleagues has conducted experiments on mechanical robustness of OPV cells in order to assess the possibility of their use on membrane foils [41]. Authors systematize possible integration of PV cells on architectural cushions into three types: mechanical integration, lamination, and direct printing, shown in Fig. 6. They also emphasize that the direct printing method is the most promising for wide-spread application, although this technique was still not sufficiently perfected. In their research, the authors test a commercially available OPV, expose it to uniaxial tensile loading and measure the conductivity and the efficiency of the cell. The aim was to check how strain affects the properties of the cell, as membrane structures are subject to large strains. The resulting stress-strain curve is given. Conducted tests showed the rupture sequence of the cell's layers. However, it has been noticed that the electrodes are damaged at low strains. The cell has $80 \%$ efficiency at the strain of $1.8 \%$. Based on the experiment results, the authors also conclude that the transparent electrode used in the cell is not mechanically robust upon large strain, unlike the metal electrode used in the same cell. This paper provides a methodology for testing future material advances in the field of PV integrated membrane structures.

Mechanical experiments on organic PV cells have also been conducted for BIPV applications which means potential use within membranes. The goal was to determine how light and how flexible OPV can be depending on the substrate material. OPV samples have been tested in laboratory conditions. Organic PV cells on plastic foils with a total thickness of $0.2 \mathrm{~mm}$ were reported to operate normally when bent to a curvature of $5 \mathrm{~mm}$ radius. It was also demonstrated that, out of the other PV cell's technologies, ultrathin OPV is characterized by the most advantageous power-to-weight ratio [27].

\subsubsection{Experimental Testing of PV-Membranes}

Fan and his team published another research in 2015 concerning the performance of OPV [42]. Unlike the previous one, this research involves OPV printed on ETFE membrane which is compared to the usual OPV printed on PET, not used as an architectural membrane due to its mechanical properties. Six different specimen types were tested, three with ETFE substrate and three with PET substrate. All ETFE specimens have an additional PMMA layer. First, results for conductance under strain of $\mathrm{Ag}$ layer on ETFE and PET were compared. Conductance of both specimens decreases rapidly for strains up to $50 \%$, however ETFE specimen shows better conductance and also much larger strain at rupture. PEDOT/Ag layers tested next show a very similar behaviour on both substrates. When comparing Ag and PEDOT/Ag layers on PET, the latter shows better conductance and lower strain at rupture. When the same layers are tested on ETFE substrate, PEDOT/Ag layer only shows better conductance up to the strain on $25 \%$. In the next part of the research, the specimens were observed under 10x microscope. Both specimens before and after stretching were studied. Specimens with ETFE show network pattern of small cracks, thus enabling these specimens' lower sensitivity to strains compared to the ones with PET. The results of this research are promising as they show better performance of specimens on ETFE substrate, which is already being used in tensile membrane structures, compared to the OPV printed on PET substrate. The results of the previous two 
researches are systematized in another paper from 2018 [43].

In 2016, Scotta with colleagues published a research about structural and electrical performances of membranes with embedded PV cells under uniaxial and biaxial stresses [44]. Unlike the previous research, the PES/PVC membrane was used, with superimposed amorphous silicon PV cell and a transparent ETFE foil as an external protection. Four different types of specimens were used, two PV integrated membranes and two membranes without PV which are used for comparison. One of each was used for uniaxial, and the other for biaxial testing. Standard tests had to be modified due to the large size of specimens dictated by the size of PV module. Ten tensile tests were conducted while the PV cells were lit with halogen lamps and the electricity power production was measured. Resulting stress-strain curves are given and warp elastic modulus is calculated. Specimens with integrated PV have a larger elastic modulus due to their composite structure. More importantly, the production of electricity is stable under both uniaxial and biaxial tests up to the stress of about $20 \mathrm{~N} / \mathrm{mm}$. The authors conclude that these results speak in favour of real-life application of such PV integrated membranes. However, it is pointed out that further tests concerning fatigue effects on mechanical and electrical behaviour of analysed integrated system need to be conducted.

$\mathrm{Hu}$ with colleagues examined a two-layer ETFE cushion with integrated amorphous silicon PV panel on the top layer in 2017 [45]. Temperature distribution on the top layer was monitored by using infrared thermography. Temperatures in different points on the PV cells and ETFE were measured. It was found that temperature was affected by solar irradiance, incident angle and surface curvature. Average temperatures of the $\mathrm{PV}$ and the membrane differed by $16.5{ }^{\circ} \mathrm{C}$, PV having larger temperatures. A theoretical thermal model was also developed in the study. The thermal model has a correlation coefficient of 0.95 and a maximum temperature difference of $3.3 \mathrm{~K}$ compared to the experimental measurements, thus proving it can predict temperatures well. Heat transfer coefficients were calculated for PV and ETFE foil and were found to be less than the usual value for single layer ETFE.

The same experimental model was also used in another study from 2016 [46] to validate numerical modelling of the photothermal performance of the structure. The thermal model of the structure was developed based on the energy balance equation, which was selected as the most appropriate since it includes all factors that affect the PV. Summer sunny and summer cloudy weather conditions were analysed. Temperature of the PV is primarily affected by the solar irradiance, and to a lesser degree by the installation angle and the ambient temperature. The proposed numerical model shows good agreement with the measured data, as the maximal temperature difference of the a-Si PV under sunny conditions is $3.3{ }^{\circ} \mathrm{C}$, and under cloudy conditions is $3.9^{\circ} \mathrm{C}$.

In another research published in $2018, \mathrm{Hu}$ with his team simultaneously investigated electrical, thermal and mechanical properties of OPV-ETFE foils [47]. Two types of specimens were tested, one with single and the other with double OPV cells integrated within two ETFE foils. Results on both types showed that voltage is independent of the stress and temperature. During the straining of specimens the stresses and temperature increase. Material properties of double OPV specimens are greater than of the single OPV, especially for the voltage where the values are more than three times larger. It is also concluded that the yield point has a significant effect on the temperature-stress correlation.

\subsection{PV Integrated in a Three Layer ETFE Structure}

Researchers $\mathrm{Hu}$ and Chen with colleagues have a series of papers on the application of PV on ETFE inflated structure. The analysed model is presented in Fig. 7. In the first paper from 2013 they propose a novel three-layer ETFE cushion with two amorphous silicon PV panels installed on the middle layer [48]. In such way the PV cells are horizontally positioned and protected from dirt, wind and rain. The research presented in this paper investigated electricity characteristics, temperatures of air and layers, the air pressure and solar irradiance during a cold winter and hot summer day. It is concluded that the electricity produced by PV panels was more than enough to supply the system for controlling the pressure, necessary for the stability of the cushion. Furthermore, PV panels increase the temperature of the inner air significantly, thus creating potential to reduce the energy consumption for heating in winter. In the next paper from 2014, the same physical model is studied under sunny and sunny to cloudy summer weather in one-day and three-day tests [49]. The results confirmed the conclusions from the previous paper. On average, the air inside the cushion is $18.1^{\circ} \mathrm{C}$ warmer than the outside air. The system's electricity feasibility has been verified.

The two following papers from 2015 present researches about thermal performances of the same physical model $[50,51]$. In addition, a numerical model was created and tested. Resulting temperature distribution and velocity distribution inside the cushion are given. The results show that obtained heat transfer coefficients are better than those of ETFE cushions without integrated PV cells. A thermal model for the PV integrated ETFE system was proposed in the following paper published in 2015 [52]. The data measured on summer sunny, summer cloudy, winter sunny and winter cloudy days were used as input for the proposed thermal model and the results were compared to those obtained on a physical model. The comparison validated the proposed model in the aspect of temperature characteristics and temperature value.

A new study in 2016 examined the overall system efficiency of the model [53]. Four sunny and mostly sunny days were used for analysis. Efficiency is greater during summer than during winter and also greater during sunny than mostly sunny days. Nominal system efficiency is $6.95 \%$ including photovoltaic electricity and thermal energy. Considering that only $27 \%$ of the area is covered with PV panels, virtual system efficiency is calculated to be $25.5 \%$. It is also noted that the temperature of the middle ETFE layer is considerably higher than of the other two, which are structural. This justifies the proposed methodology of positioning the PV cells on the middle layer, since increased temperature reduces the mechanical properties of ETFE. To explore this effect, another study was conducted and presented in 2016 [54]. It was found by 
testing that increase of temperature of ETFE results in decrease of its elastic modulus and yield stress, while elongation strain increased. A simulation of design conditions and a parameter study with varying pressure and pre-stress were performed. Maximum structural behaviour was found to be within the yield region and results recorded on top layer were more significant than those on the bottom layer.

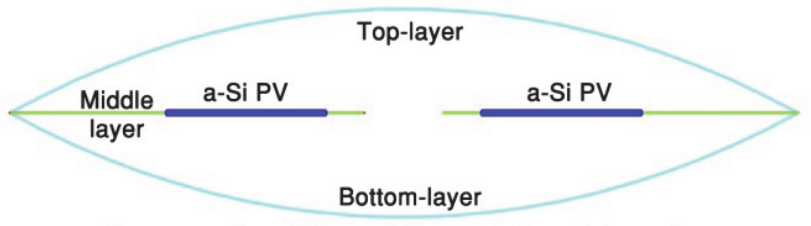

Cross-sectional view of the experimental mock-up

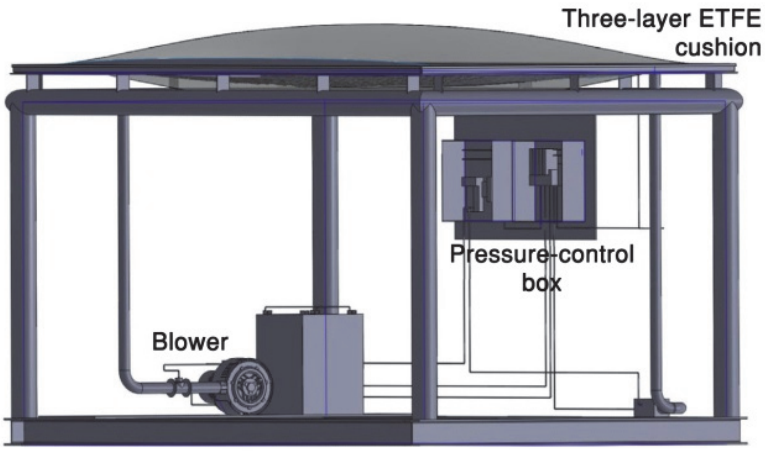

Schematic diagram of the experimental mock-up

Figure 7 Schematic diagram (bottom) and cross-sectional view (top) of the experimental mock-up (authors, based on [52])

Yin with colleagues conducted research in 2020 on a mathematical model of the PV integrated three layer ETFE structure [55]. They analysed the temperature distribution, surface stresses and displacements of ETFE layers, and streamline and fluid characteristics of internal airflow. The temperature of the surfaces is primarily influenced by solar radiation and heat transfer from the PV. Bottom layer is cooler due to shading from the upper layers and due to the a-Si PV installed on the middle layer. The PV panels induce an average temperature difference of $15^{\circ} \mathrm{C}$ on the same layer. Air temperature is high and above $70{ }^{\circ} \mathrm{C}$, especially in the area around the PV panels. This reduces the efficiency of the PV, but creates an opportunity for heat collection. Water pipes placed below the PV could reduce the inside temperature and thus increase the PV efficiency, while at the same time providing hot water and not shading the PV. Maximum stresses of the upper and lower layer occur at the middle of the longer cushion edge. Due to effects of different temperatures to the ETFE, the factor of safety is calculated. In the worst case, the factor of safety is close to 2 and displacements are $22.5 \mathrm{~mm}$, which are sufficient for a safe and stable cushion roof. It is concluded that thermal, structural and fluid behaviours are dependent one on another.

In 2017, Abdolzadeh with colleagues used a previous experiment to validate a new numerical model of the three layer ETFE cushion with integrated a-Si PV on the middle layer [56]. They monitored thermal and electrical performances of the structure under sunny weather conditions. Two different options were analysed, the cushion with steady state mass flow and the cushion with the air pressure regulator system. The authors point out that in this study, for the first time ever, the cushion air pressure regulator system is used in modelling of such structures. Comparison of results of measurement and numerical analysis proved reasonable accuracy of the proposed numerical model. The steady mass flow case has higher efficiency and higher average output power; however, it consumes most of the power.

\subsection{Adaptable Structural Shapes}

Lienhart with colleagues presented their work on the Softhouse project in 2013 [57]. With regard to the topic of this paper, Softhouse project is interesting as it has a façade composed of tensile membrane strips equipped with PV cells. In addition, this building also has a roof covered with glass fiber reinforced plastic boards also equipped with PV cells. Innovation implemented in the project is the shape change of the façade and the roof performed in order to maximize the effectiveness of the PV cells. Since static and fixed PV cells do not fully utilize the energy from the Sun, the idea was to create an adaptive façade/roof system that would provide optimal orientation of the cells. The boards on the roof change their curvature, driven by a mechanical system, in order to respond to the change of the Sun angle during the year. At the same time, the membrane façade is twisted in order to answer to daily movement of the Sun. These two modes of shape adaptation are combined in order to get the most suitable orientation of the PV cells throughout every day of the year. The importance of this work, in the sense of PV-membrane integration, is in proposing and testing the idea of shape-changing of the membrane in order to fully utilize the attached PV cells. The applied concept of twisting membrane strips should serve as a starting point in further developing of this idea.

Pronk with colleagues present in their paper from 2013 a different approach to creating adaptable roofs [58]. Their idea is to start from known tensegrity structures and transform them into kinetic structures that would have an optimal shape for harvesting the solar energy. They use Geiger dome, which is the alteration of the Fuller dome, and explore its possibilities for shape-change. The membrane with integrated PV cells is used only as a cover of the dome. It is intended that the membrane slides over the supports as the supports move, but this concept needs to be improved. Two basic options for creating movement are: changing the length of the bars and changing the length of the strings. These result in either sliding or hinging movement of the dome. In the presented research the option with changing the length of the strings is further analysed. To create a kinetic dome by hinging, the structure needs to be modified to a hex-tri-hex configuration. Scaled physical models were created for testing. In addition, software was used to prepare the 1:1 model of the structure. The model with a span of $4 \mathrm{~m}$ was built and it is planned for a $10 \mathrm{~m}$ span model to be produced. The angle of the PV cells on this structure can be varied from 27 to $65^{\circ}$. In this way the feasibility of the starting idea was proven, although there are still issues concerning the weight of the structure and the detailing. Further tests on the energy consumption of the mechanical system for larger scale structures would have to be conducted. 


\section{DISCUSSION}

Thorough analysis of the presented research showed three main types of properties affected by the integration of PV into tensile membrane structures; these are thermal, energy, and structural properties. The main variables influencing these properties are the integration method and the geometry of the PV-membrane structures. The PVmembrane integration method as an influence parameter is further divided to the type of integration technology, the position of $\mathrm{PV}$ in the foil layers, and the substrate type for PV. PV-membrane geometry consists of PV geometry and tensile membrane geometry. Tab. 1 provides an overview of the topics researched in the analysed papers.

An investigation of the executed PV-membrane structures was not a subject of this paper; however, the need for detailed analysis of such structures is identified. Several case studies and prototypes of built PV-membrane structures are presented in literature [59-62]. On the basis of the executed structures, further research on life cycle assessment, maintenance and other utility problems arising from the integration of PV cells with membrane structures in real conditions is highly required. Another interesting and equally poorly recognized field of research is the influence of various PV cells technology on aesthetics of the membrane structures (their texture, color, artistic effects) and its energy consequences. The aesthetic potential of PV technology for BIPV applications including energy related aspects has been presented in literature, e.g. [63-65]. Finally, the cost analysis of application of PV-membrane structures should be further explored along with the review of the existing and planned PV-membrane structures. This issue could potentially be one of the key factors in either promoting or limiting the PV-membrane integration.

With research summarized in Tab. 1, it is clear which areas have been neglected so far. The most obvious is the static form of the tensile membrane that has not been explored at all. Although a couple of researches are aimed at adapting the form of the structure, which would certainly increase the efficiency of the system, it is not elaborated how different static shapes of the structure affect the energy properties. Due to the variety of specific forms of tensile membrane structures, further research on this matter is definitely needed. As a result, this would give a set of guidelines on how to maximize the potential of integration of PV cells into tensile membrane structures. Another area insufficiently explored is the PV geometry, both in the sense of the curvature of a single cell and the area covered by the cells. The former should be further investigated with respect to its influence on the structural properties of the system, while the latter should be explored for influence on thermal properties. It is interesting to notice that there is yet no comparison of how different types of integration technology affect energy and thermal properties of the integrated system.

After careful analysis of the available research it was concluded that even the areas already investigated according to Tab. 1 could still benefit from future researches. One of the examples is the position of PV in different foil structure layers. Despite being already researched concerning the influence on the three main properties of the system, possible further analysis could combine this parameter with the geometry of the membrane and investigate the comparison of results, while varying these parameters. The conclusions from such analysis would be helpful in increasing the efficiency of the system.

Based on the presented research it can be concluded that investigations of PV integration are conducted relatively independently on textile and foil membranes. With ETFE structures, there are options to integrate PV into top, middle or bottom layer of the cushion. In each case, PV will provide shading [66]. As ETFE foils are selfcleaning and waterproof, and have excellent light transmittance, the top cushion layer provides a good protection for the PV cells. In case that the temperatures of the cells get too high and thus impair the ETFE structural properties, a middle non-structural ETFE layer can be used as their support, as proposed by some of the presented studies. It is noticed that PV integration on ETFE foil cushions offers more possibilities than on woven membranes. Integration on single layer woven membranes would inevitably lead to wind cooling down the cells, which would increase the efficiency of the cells, but could possibly have a negative effect on the connection between the membrane and the cell. In multi-layered textile membranes, integration on lower layers is not possible as the textile membranes are not transparent but rather translucent. However, integration of PV into textile membranes should in no case be neglected. Textile membranes constitute a large part of the built tensile structures, and such membranes are sometimes used as cladding in non-tensile structures. Currently, they also provide much larger spans than foil membranes. Therefore, it is concluded that further research needs to be aimed towards integration of PV into textile membranes.

While investigating the area of PV-membrane integration, certain options and issues were recorded. They are given in Tab. 2, which summarizes the observed possibilities and problems of integration of PV into tensile membrane structures.

Table 1 Estimation of the influence of PV-membrane integration method and its structure geometry on PV-membrane's thermal, energy and structural properties (authors)

\begin{tabular}{|c|c|c|c|c|}
\hline & & \multicolumn{3}{|c|}{ influence on PV-membrane structure properties: } \\
\hline & & Thermal properties & energy properties & Structural properties \\
\hline \multirow{3}{*}{$\begin{array}{c}\text { PV-membrane integration } \\
\text { method }\end{array}$} & type of integration technology & & & + \\
\hline & position of PV in the foil structur layers & + & + & + \\
\hline & substrate type for PV & & + & + \\
\hline \multirow{3}{*}{$\begin{array}{l}\text { PV-membrane structure } \\
\text { geometry }\end{array}$} & PV geometry & & + & \\
\hline & static membrane geometry & & & \\
\hline & kinetic membrane geometry & & + & + \\
\hline
\end{tabular}




\begin{tabular}{|c|c|c|c|}
\hline & & Possibilities & Problems \\
\hline \multirow{3}{*}{$\begin{array}{l}\text { PV-membrane } \\
\text { integration method }\end{array}$} & $\begin{array}{l}\text { type of integration } \\
\text { technology }\end{array}$ & $\begin{array}{l}\text { mechanical, lamination and direct printing of OPV on } \\
\text { ETFE foil; } \\
\text { superimposing a-Si immediately after coating polyester } \\
\text { with PVC and passing through rollers before } \\
\text { polymerization of protective EFTE layer; } \\
\text { mounting flexible PV on PTFE/glass fiber membrane } \\
\text { through multi-layer attachment system }\end{array}$ & $\begin{array}{l}\text { the first two possibilities do not allow the } \\
\text { deinstallation of PV; } \\
\text { the third possibility is relatively complex for } \\
\text { installation }\end{array}$ \\
\hline & $\begin{array}{l}\text { position of PV in the } \\
\text { foil structure layers }\end{array}$ & $\begin{array}{l}\text { preferable intermediate layer in three layer ETFE } \\
\text { cushions (improvement of thermal insulation properties). } \\
\text { In other cases-external layer }\end{array}$ & $\begin{array}{c}\text { when located on structural layer, damages of } \\
\text { the foil structure possible due to high } \\
\text { temperatures (mechanical properties } \\
\text { impaired) }\end{array}$ \\
\hline & substrate type of PV & $\begin{array}{l}\text { ETFE foil as a PV substrate positively affects OPV } \\
\text { efficiency, compared to PET substrate }\end{array}$ & $\begin{array}{c}\text { printing on textile membranes not } \\
\text { researched }\end{array}$ \\
\hline \multirow{3}{*}{$\begin{array}{l}\text { PV-membrane } \\
\text { structure geometry }\end{array}$} & PV geometry & $\begin{array}{l}\text { flat and curved PV panels integration possible } \\
\text { possibility to cover whole membrane or parts that would } \\
\text { provide for best efficiency }\end{array}$ & $\begin{array}{l}\text { rupture sequence of OPV cell's layers. The } \\
\text { electrodes are damaged at low strains; the } \\
\text { cell has } 80 \% \text { efficiency at strain of } 1.8 \% \text {; } \\
\text { slight efficiency losses in case of curved PV } \\
\text { panels }\end{array}$ \\
\hline & $\begin{array}{l}\text { static membrane } \\
\text { geometry }\end{array}$ & $\begin{array}{l}\text { single and double curvatures possible } \\
\text { different curvature amounts possible }\end{array}$ & $\begin{array}{c}\text { limited mainly due to PV requirements } \\
\text { concerning orientation, tilt angle and lack of } \\
\text { shadowing; } \\
\text { parametric design required for double } \\
\text { curvature }\end{array}$ \\
\hline & $\begin{array}{l}\text { kinetic membrane } \\
\text { geometry }\end{array}$ & higher efficiency compared to static membranes & $\begin{array}{l}\text { energy used for changing the shape; } \\
\text { more complex supporting structure }\end{array}$ \\
\hline
\end{tabular}

\section{CONCLUSIONS}

This paper presents a state of the art review on the topic of PV integrated membrane structures. First, properties of tensile membrane structures are presented. Currently, the greatest disadvantage of these structures are their inferior thermal properties, resulting in a large amount of energy being used for heating and cooling. It is unlikely that thermal resistance of these structures will be significantly improved, since they are indispensably made of extremely thin materials. One of the possible ways of increasing their energy efficiency is the integration of PV technology in tensile membranes. Technological evolution of PV technology and its application in buildings systematized according to architectural generations is given in this paper. Recent advantages in the PV technology made the integration much easier, cheaper and more appealing. PV cells are now thin, flexible and environmentally friendly. However, they too have their downsides, most notably, their efficiency needs to be increased. After presenting these two separate fields of research, available scientific researches concerning PV integrated tensile membrane structures are shown. Publications are systematized according to the primary investigated topic. Most important findings and conclusions from each research are selected and displayed in this paper. In the last section, discussion and overall analysis of the state of the art in the field of PV integrated tensile membrane structures are given.

The earliest analysed research about a possible integration of PV into tensile membrane structures is less than a decade old. The idea about this integration being so novel, there are still a lot of issues to be perfected. In addition, both of these independent areas are still developing, with PV technology progressing especially rapidly. This makes their integration an on-going process that is still evolving and has yet to reach its peak. The number of scientific research in this area is still not sufficient to have enough knowledge that would enable the extensive practical application of this integrated technological/structural system. Due to this, a need for a review of the published literature was observed. This paper was created as a response to the noted problem. It aimed to systematize existing publications and identify the areas which are under-researched. It is concluded that in the last 10 years a huge progress has been made in research about this topic. Available benefits of the integration of PV into tensile membranes will continue to drive scientific interest in this field. Therefore, it is expected that additional exploration of this topic will be conducted in the near future. This paper should serve as a starting point for researchers interested in investigating the field by helping them to grasp what is already done and what areas are suitable for new explorations. Furthermore, by highlighting the possibilities and problems of PVmembrane integration, the paper should assist in selecting the most suitable integration system for specific projects and thus, in future, help in achieving widespread practical application of the PV-membrane structures.

\section{REFERENCES}

[1] Llorens, J. I. (2015). Fabric Structures in Architecture. Elsevier.

[2] ASCE. (2013). Tensile Fabric Structures: Design, Analysis, and Construction. Reston, VA.

[3] Forster, B. \& Mollaert, M. (2004). European Design Guide for Tensile Surface Structures.

[4] Stranghoner, N., Uhlemann, J., Bilginoglu, F., et al. (2016). Prospect for European Guidance for the Structural Design of Tensile Membrane Structures. European Commission, Joint Research Centre.

[5] ASCE. (2010). Tensile Membrane Structures. Reston, VA. https://doi.org/10.1061/9780784410974

[6] Machacek, J., \& Jermoljev, D. (2017). Steel structures in interaction with non-metallic membranes. Journal of Civil Engineering and Management, 23(3), 368-377. https://doi.org/10.3846/13923730.2015.1128482

[7] Milošević, V. (2015). Dependence of membrane deflection on the position and intensity of point loads. Structural Engineering International, 1, 20-25. https://doi.org/10.2749/101686614X14043795570372 
[8] Milošević, V., Marković, B., \& Stojić, D. (2018). Effects of point loads on membrane structures. Građevinar, 70(12), 1033-41. https://doi.org/10.14256/JCE.1670.2016

[9] Milošević, V., Kostić, D., \& Milošević, J. (2020). Tensile membrane structure forces dependence on different parameters under point load action. Gradevinski materijali $i$ konstrukcije, 63(1), 29-43 https://doi.org/10.5937/GRMK2001029M

[10] Devulder, T., Wilson, R., \& Chilton, R. (2007). The Thermal Behaviour of Buildings Incorporating Single Skin Tensile Membrane Structures. International Journal of Low Carbon Technologies, 2, 195-213. https://doi.org/10.1093/ijlct/2.2.195

[11] ElNokaly, A. M., Chilton, J. C., \& Wilson, R. (2003). Environmental Performance of Spaces Enclosed or SemiEnclosed by Fabric Membrane Structures. Paper presented at the Textile Composites and Inflatable Structures. Barcelona, Spain.

[12] He, J. \& Hoyano, A. (2009). Measurement and simulation of the thermal environment in the built space under a membrane structure. Building and Environment, 44, 1119-27. https://doi.org/10.1016/j.buildenv.2008.08.003

[13] He, J. \& Hoyano, A. (2010). Measurement and evaluation of the summer microclimate in the semi-enclosured space under a membrane structure. Building and Environment, 45, 23042. https://doi.org/10.1016/j.buildenv.2009.06.006

[14] Reimann, K., Kneer, A., Weißhuhn, C., \& Blum, R. (2011). A simulation model for the yearly energy demand of buildings with two-or-more-layered textle roofs. $V$ Structural Membranes 2011, 330-339.

[15] Kostić, D., Milošević, V., Bogdanović, V., Vasov, M., \& Vučur, A. (2018). Influence of single and double membrane roofs on thermal behaviour of enclosed space. Technical Gazette, 25(1), 188-96. https://doi.org/10.17559/TV-20161205160405

[16] Marchwiński, J. (2012). Fasady fotowoltaiczne. Technologia $P V w$ architekturze Photovoltaic Facades. PV Technology in Architecture, 35-42. WSEiZ Publishing Office.

[17] Blakers, A., Zin, N., McIntosh, K. R., \& Fong K. (2013). High Efficiency Silicon Solar Cells. Energy Procedia, 33, 110. https://doi.org/10.1016/j.egypro.2013.05.033

[18] Kibria, M. T., Ahammed, A., Sony, S. M., Hossain, F., \& Shams, U. I. (2015). A Review: Comparative studies on different generation solar cells technology. $5^{\text {th }}$ International Conference on Environmental Aspects of Bangladesh, 51-53.

[19] Sun, Y., Shanks, K., Baig, H., Zhang, W., Hao, X., Li, Y., He, B., Wilson, R., Liu, H., Sundaram, S., Jingquan, Z., Lingzhi, X., Tapas, M., \& Yupeng, W. (2018). Integrated semi-transparent cadmium telluride photovoltaic glazing into windows: Energy and daylight performance for different architecture design. Applied Energy, 231, 972-984. https://doi.org/10.1016/j.apenergy.2018.09.133

[20] Wang, D., Yang, R., Wu, L., Shen, K., \& Wang, D. (2018). Band alignment of CdTe with MoOx oxide and fabrication of high efficiency CdTe solar cells. Solar Energy, 162, 63745. https://doi.org/10.1016/j.solener.2018.01.031

[21] Sarniak, M. (2008). Podstawy fotowoltaiki Basics of Photovoltaics. Warsaw University of Technology Publishing Office.

[22] Žnidarec, M., Šljivac, D., \& Došen, D. (2019). Performance and Empirical Analysis of Photovoltaic Modules Made of Different Technologies Using Capacity Evaluation Method. Technical Gazette, 26(6), 1585-1592. https://doi.org/10.17559/TV-20181003182104

[23] Kaltenbrunner, M., White, M. S., Głowacki, E. D., Tsuyoshi, S., Takao, S., Niyazi, S. S., \& Siegfried, B. (2012). Ultrathin and lightweight organic solar cells with high flexibility. Nat Commun, 3, 770. https://doi.org/10.1038/ncomms1772

[24] Prasad, S. V. D., Krishnanaik, V., \& Babu, K. R. (2013). Analysis of Organic Photovoltaic Cell. International Journal of Science and Modern Engineering, 1(9), 20-23.
[25] Mullasery, D. J. (2016). Perovskite solar cells degradation solutions. Technical Report, 637-645, University of British Columbia-Vancouver.

[26] Park, N. G. (2015). Perovskite solar cells: an emerging photovoltaic technology. Materials Today, 18(2), 65-72. https://doi.org/10.1016/j.mattod.2014.07.007

[27] Hu, Y., Chu, Y., Wang, Q., Zhihui, Z., Yue, M., Anyi, M., Yaoguang, R., \& Hongwei, H. (2019). Standardizing Perovskite Solar Modules beyond Cells. Joule, 3(9), 20762085. https://doi.org/10.1016/j.joule.2019.08.015

[28] Ritter, A. (2007). Smart materials in architecture, interior architecture and design. Birkhauser.

[29] Spooner, E. (2020). Organic Photovoltaics vs $3^{\text {rd }}$-Generation Solar Cell Technologies. University of Sheffield in collaboration with Ossila. https://www.ossila.com/pages/organic-photovoltaics-vs3rd-gen-solar-tech

[30] Marchwiński， J. (2015). Fotowoltaika zintegrowana z budynkiem (BIPV) w kontekście kształtowania form architektonicznych Building Integrated Photovoltaics (BIPV) in the context of shaping building's form. Kontekst energetyczny ksztaltowania form architektonicznych Architectural context of shaping of building's forms in research and design, 147-167.

[31] Reijenga, T. \& Kaan, H. (2011). PV in Architecture. In A. Lucue \& S. Hegedus (Eds.), Handbook of Photovoltaic Science and Engineering, 1043-1077. https://doi.org/10.1002/9780470974704.ch23

[32] Riaz, A., Liang, R., Zhou, C., \& Zhang, J. (2020). A review on the application of photovoltaic thermal systems for building facades. Building Services Engineering Research and Technology, 41, 86-107. https://doi.org/10.1177/0143624419845117

[33] Marchwiński, J. (2010). PV Technology in buildings elevations. In A. Sayigh(Ed.), World Energy Renewable Energy Congress XI, 514-519.

[34] Ferwagner, T. (2011). Lightweight photovoltaics. $V$ Structural Membranes 2011, 283-292.

[35] Ghosh, A. \& Norton, B. (2018). Advances in switchable and highly insulating autonomous (self powered) glazing systems for adaptive low energy buildings. Renewable Energy, 126, 1003-31. https://doi.org/10.1016/j.renene.2018.04.038

[36] Zanelli, A., Monticelli, C., Beccarelli, P., \& Ibrahim, H. M. (2011). Experimental manufacture of a pneumatic cushion made of ETFE foils and OPV cells. V Structural Membranes 2011, 271-282.

[37] Zanelli, A., Beccarelli, P., Monticelli, C., Maffei, R., \& Ibrahim, H. M. (2012). Technical and manufacturing aspects in order to create a smart façade system with OPV integrated into ETFE foils. International Symposia IASS-APCS. IASS.

[38] Ibrahim, M. H., Zanelli, A., \& Cremers, J. (2013). The Structural Behaviour of PTFE/Glass Fabric Structures Integrating Flexible Photovoltaic Modules. VI Structural Membranes 2013, 290-299.

[39] Ibrahim, M. H., Wagdy, A., Beccarelli, P., Carpenter, R., \& Chilton, J. (2016). Applicability of flexible photovoltaic modules onto membrane structures using grasshopper integrative model. Proceedia Engineering, 155, 379-87. https://doi.org/10.1016/j.proeng.2016.08.041

[40] Ibrahim, A. H. \& Beccarelli P. (2017). Performance of Curved Organic Photovoltaics Modules for Membranes Integration: Solar Simulation Tests. Viii Structural Membranes 2017, 141-46.

[41] Fan, Z., Garbugli, M., Monticelli, C., Caironi, M., \& Zanelli A. (2013). Mechanical robustness investigation of organic photovoltaics for membrane integrated flexible solar cells. International Association for Shell and Spatial Structures (IASS) WG 18 International Seminar on Environmentally Compatible Structures, 37-60. 
[42] Fan, Z., De Bastani, M., Monticelli, C., \& Zanelli, A. (2015). Performance investigation of organic photovoltaic layers on architectural membrane. $9^{\text {th }}$ International Energy Forum on Advanced Building Skins, 1255-69.

[43] Fan, Z., De Bastiani, M., Garbugli, M., Monticelli, C., Zanelli, A., \& Caironi, M. (2018). Experimental investigation of the mechanical robustness of a commercial module and membrane-printed functional layers for flexible organic solar cells. Composites Part B,147, 69-75. https://doi.org/10.1016/j.compositesb.2018.04.007

[44] Scotta, R., Lazzari, M., Stecca, E., Di Massimo, R., \& Vitaliani, R. (2016). Membranes with embedded photovoltaic flexible cells: Structural and electrical performances under uniaxial and biaxial stresses. Composite Structures, 157, 111-20. https://doi.org/10.1016/j.compstruct.2016.08.003

[45] Hu, J. H., Chen, W. J., Liu, Y., Zhao, B., Yang, D., \& Ge, B. (2017). Two-layer ETFE cushions integrated flexible photovoltaics: Prototype development and thermal performance assessment. Energy and Buildings, 141, 238-46. https://doi.org/10.1016/j.enbuild.2017.02.038

[46] Zhao, B., Hu, J., Chen, W., Zhenyu, Q., Jinyu, Z., Yegao, Q., \& Binbin, G. (2016). Photothermal performance of an amorphous silicon photovoltaic panel integrated in a membrane structure. J Phys D: Appl Phys, 49, 395601. https://doi.org/10.1088/0022-3727/49/39/395601

[47] Hu, J. H., Chen, W. J., Yin, Y., Li, Y., Yang, D., Wang, H., \& Zhang, X. (2018). Electrical-thermal-mechanical properties of multifunctional OPV-ETFE foils for large-span transparent membrane buildings. Polymer Testing, 66, 394402. https://doi.org/10.1016/j.polymertesting.2018.01.036

[48] Chen, W. J., Hu, J. H., \& Song, H. (2013). Novel BIPV/T ETFE Cushion. Vi Structural Membranes 2013, 363-374.

[49] Hu, J. H., Chen, W. J., Zhao, B., \& Song, H. (2014). Experimental studies on summer performance and feasibility of a BIPV/T ethylene tetrafluoroethylene (ETFE) cushion structure system. Energy and Buildings, 69, 394-406. https://doi.org/10.1016/j.enbuild.2013.10.033

[50] Hu, J. H., Chen, W. J., Zhao, B., Cai, Q. Y., Qiu, Z. Y., \& Song, H. (2015). Estimation of Thermal Performance of PVETFE Cushion Roof. Vii Structural Membranes 2015, 21222.

[51] Hu, J. H., Chen, W. J., Qiu, Z. Y., Zhao, B., Zhou, J., \& Qu, Y. (2015). Thermal performances of ETFE cushion roof integrated amorphous silicon photovoltaic. Energy Conversion and Management, 106, 1201-1211. https://doi.org/10.1016/j.enconman.2015.10.008

[52] Zhao, B., Chen, W. J., Hu, J. H., Qiu, Z., Qu, Y., \& Ge, B. (2015). A thermal model for amorphous silicon photovoltaic integrated in ETFE cushion roofs. Energy Conversion and Management, 100, 440-48. https://doi.org/10.1016/j.enconman.2015.04.062

[53] Hu, J. H., Chen, W. J., Yang, D., Zhao, B., Song, H., \& Ge, B. (2016). Energy performance of ETFE cushion roof integrated photovoltaic/thermal system on hot and cold days. Applied Energy, 173, 40-51. https://doi.org/10.1016/j.apenergy.2016.03.111

[54] Hu, J. H., Chen, W. J., Cai, Q., Gao, C., Zhao, B., Qiu, Z. Y., \& Qu, Y. (2016). Structural behavior of the PV-ETFE cushion roof. Thin-Walled Structures, 101, 169-80. https://doi.org/10.1016/j.tws.2015.12.024

[55] Yin, Y., Chen, W., Hu, J., et al. (2020). Photothermalstructural-fluid behaviors of PV-ETFE cushion roof in summer: Numerical analysis using three-dimensional multiphysics model. Energy Build, 228, 110448. https://doi.org/10.1016/j.enbuild.2020.110448

[56] Abdolzadeh, M., Sadeqkhani, M., \& Ahmadi, A. (2017). Computational modeling of a BIPV/T ethylene tetrafluoroethylen (ETFE) cushion structure roof. Energy, 133, 998-1012. https://doi.org/10.1016/j.energy.2017.05.144

[57] Lienhard, J., Riederer, J., Jungjohann, H., Oppe, M., \& Knippers, J. (2013). Multifunctional Adaptive Façade at Iba 2013; Design Studies for an Integral Energy Harvesting Façade Shading System. VI Structural Membranes 2013, 473-81.

[58] Pronk, A. D. C., Dominicus, M. M. T., \& da Conceição van Nieuwenhuizen, J. B. (2013). Kinetic Geiger dome with photovoltaic panels. VI Structural Membranes 2013, 461-72.

[59] Moritz, K. (2019). Building Integrated Photovoltaic (BIPV) applications with ETFE-Films. Tensi Net Symposium 2019, 558-69.

[60] Orhon, A. V. (2016). Integration of photovoltaics into tensile and inflatable structures. Solar Conference and Exhibition, 454-462.

[61] Cremers, J. \& Lausch, F. (2008). Pv Flexibles-Photovoltaics Integrated in Translucent PTFE-And Transparent ETFEMembranes Structures. 23 ${ }^{\text {rd }}$ European Photovoltaic Solar Energy Conference and Exhibition, 3520-3522.

[62] Cremers, J. \& Lausch, F. (2009). Flexible Photovoltaics Integrated in Translucent PTFE/Glass and Transparent ETFE Membrane Structures. $5^{\text {th }}$ User Forum Thin-Film Photovoltaics.

[63] Pelle, M., Lucchi, E., Maturi, L., Astigarraga, A., \& Causone, F. (2020). Coloured BIPV Technologies: Methodological and Experimental Assessment for Architecturally Sensitive Areas. Energies, 13(17), 1-21. https://doi.org/10.3390/en13174506

[64] Royset, A., Kolas, T., \& Jelle, B. T. (2020). Coloured building integrated photovoltaics: Influence on energy effciency. Energy \& Buildings, 208, 109623. https://doi.org/10.1016/j.enbuild.2019.109623

[65] IEA. (2019). Coloured BIPV. Market, Research and Development. Photovoltaic Power System Program.Report IEA-PVPS T15-07:2019.

[66] Cremers, J. (2011). Energy saving design of membrane building envelopes. V Structural Membranes 2011, 147-57.

\section{Contact information:}

Vuk MILOŠEVIĆ, Assistant Professor, PhD, M.Eng

Faculty of Civil Engineering and Architecture, University of Niš Aleksandra Medvedeva 14, 18000 Niš, Serbia

E-mail: vukamer@yahoo.com

\section{Janusz MARCHWIŃSKI, Associate Professor, PhD Arch.}

(Corresponding author)

Faculty of Architecture, University of Ecology and Management in Warsaw Olszewska 12, 00-792 Warsaw, Poland

E-mail: j.marchwinski@wseiz.pl 